\title{
Maryna Bilyk
}

Kremenchuk Mykhailo Ostrogradskyi National University

e-mail: marina.bilick@gmail.com

ORCID: 0000-0002-9660-3708

\section{Oleh Kratt}

Kyiv National I. K. Karpenko-Kary Theatre, Cinema and Television University

e-mail: kratt1960@gmail.com

ORCID: 0000-0002-3738-2239

\section{Kateryna Pryakhina}

Kremenchuk Mykhailo Ostrogradskyi National University

e-mail: katerinapryakhina@gmail.com

ORCID: 0000-0002-5747-9492

\section{Iryna Trunina}

Kremenchuk Mykhailo Ostrogradskyi National University e-mail: truninairina0@gmail.com

ORCID: 0000-0002-7416-1830

\section{CITY BRANDING AS A TOOL OF PUBLIC ADMINISTRATION}

\section{TWORZENIE MARKI MIASTA}

\section{JAKO NARZĘDZIE ADMINISTRACJI PUBLICZNEJ}

DOI: $10.15611 / \mathrm{br} .2021 .1 .02$

JEL Classification: H83, M38, D73

(C) 2021 Maryna Bilyk, Oleh Kratt, Kateryna Pryakhina, Iryna Trunina

This is an open access article distributed under the Creative Commons Attribution-Non-

Commercial-NoDerivs license (http://creativecommons.org/licenses/by-nc-nd/3.0/)

Quote as: Bilyk, M., Kratt, O., Pryakhina, K. \& Trunina, I. (2021). City branding as a tool of public administration. Biblioteka Regionalisty. Regional Journal, (21). 


\begin{abstract}
The article examines the formation of the city brand as a tool of public administration for increased competitiveness. The authors present a definition of 'city branding' and marketing features of territorial branding, scientific tools developed for diagnostics, as well as development of the territorial brand, and directions of promotion of the city brand as a factor of increasing its competitiveness. The purpose was a theoretical and practical justification for the formation of the city's brand as a way to increase its competitiveness. The methodological basis of the study was a set of theoretical and empirical methods of scientific knowledge: theoretical generalization in order to clarify the basic theoretical and methodological foundations of the concept of branding the city; analysis and synthesis in determining the strategic directions and target audiences of the city brand; the formation of directions for the promotion of the city brand; visual of the results of the study.
\end{abstract}

Keywords: brand, city branding, territory branding, public administration.

Streszczenie: W artykule omówiono kształtowanie marki miasta jako narzędzia administracji publicznej służącego podnoszeniu konkurencyjności. Scharakteryzowano definicję „brandingu miasta” i cechy marketingowe brandingu terytorialnego; opracowane narzędzia naukowe do diagnostyki i rozwoju marki terytorialnej; rozwijane są kierunki promocji marki miasta jako czynnika wzrostu jego konkurencyjności. Celem jest teoretyczne i praktyczne uzasadnienie kształtowania marki miasta jako sposobu na zwiększenie jego konkurencyjności. Podstawę metodologiczną opracowania stanowi zespół teoretycznych i empirycznych metod poznania naukowego: uogólnienie teoretyczne - w celu wyjaśnienia podstaw teoretycznych i metodologicznych koncepcji brandingu miasta; analiza i synteza - w określaniu kierunków strategicznych i docelowych odbiorców marki miasta, kształtowanie kierunków promocji marki miasta; obraz graficzny z wizualnym przedstawieniem wyników badania.

Słowa kluczowe: marka, branding miasta, branding terytorium, administracja publiczna.

\title{
1. Introduction
}

The modern realities of the development of society and the state require talking not only about the competition of commodity brands, but also about the competition of territories. Territorial competition is, first of all, the market of investments, tourism, the market of the labour force ready to live and work in the given territory. Territory branding occupies an important place in the political, social and economic policy of the state and its regions. The success of the territory depends not only on the economic and geographical location, but also on such factors as the presence and implementation of the strategy of the region and the self-identification of its inhabitants. A successful brand of the territory allows it to compete effectively for investment and tourist flows.

Therefore, in conditions of growing competition between cities there is an increasing need to emphasize the uniqueness of the given city or give it a new history that could emphasize its benefits, attract the attention of target audiences and increase its competitiveness. In turn, the creation and promotion of local brands not only improves the image of cities, but also as a result of investment and tourism, brings a flow of financial resources, educated staff, promotes infrastructure, and supports local entrepreneurship, all of which favourably affects the development of the city 
through the creation of new jobs as well as contributes to the local budget. All of this necessitates the introduction of territorial branding as a tool of public administration.

\section{Definition of 'city branding' and its role in city development}

City branding is a purposeful activity for the creation and development of the city brand. The brand is formed on the basis of a clearly expressed positive image of the city, which is based on a unique opportunity to meet certain needs of consumers. Nowadays academic opinions on the concept of city branding are very diverse, so there is no single definition. Thus, it is necessary to consider in more detail the existing definitions. The main approaches to the definition of this concept are given in Table 1.

Table 1. Basic approaches to defining city branding and territory branding

\begin{tabular}{|l|l|}
\hline \multicolumn{1}{|c|}{ Author } & \multicolumn{1}{c|}{ Definition } \\
\hline Zhitar O. (2009) & $\begin{array}{l}\text { Territory branding is a process of brand formation and management, which in- } \\
\text { cludes its creation, strengthening, promotion, renewal, possible repositioning, } \\
\text { rebranding. }\end{array}$ \\
\hline $\begin{array}{l}\text { Soldatenko I., } \\
\text { Posylnyi I. } \\
(2019)\end{array}$ & $\begin{array}{l}\text { City branding is a multifaceted process, a set of marketing, advertising, communi- } \\
\text { cation and other actions, the purpose of which is to form a successful image of the } \\
\text { city, i.e. the vision of the city formed by residents and non-residents, based on what } \\
\text { information they receive about the city. }\end{array}$ \\
\hline $\begin{array}{l}\text { Ripka Yu. } \\
(2011)\end{array}$ & $\begin{array}{l}\text { Local branding can be understood as a strategy to increase competitiveness in order } \\
\text { to conquer foreign markets, attract investors, tourists, new residents and skilled } \\
\text { migrants. }\end{array}$ \\
\hline $\begin{array}{l}\text { Kolesnytska N. } \\
(2012)\end{array}$ & $\begin{array}{l}\text { Territory branding is a purposeful process of formation, presentation and promo- } \\
\text { tion of a certain territory on the world market as its competitive and liquid unit. }\end{array}$ \\
\hline Anholt S. (2010) & $\begin{array}{l}\text { City branding is a systematic process of coordinating actions, behavior, invest- } \\
\text { ments, innovations and communications of the city to implement a strategy of } \\
\text { competitive identity. }\end{array}$ \\
\hline $\begin{array}{l}\text { Kavaratzis M., } \\
\text { Ashworth G. } \\
(2005)\end{array}$ & $\begin{array}{l}\text { The brand of the territory is a multidimensional construct consisting of functional, } \\
\text { emotional and material elements, which together create a unique set of associations } \\
\text { with a place in the public consciousness. }\end{array}$ \\
\hline $\begin{array}{l}\text { Olefirenko O. } \\
\text { (n.d.) }\end{array}$ & $\begin{array}{l}\text { Branding of the territory is aimed at overcoming the shortage of tangible and intan- } \\
\text { gible resources in the region, it is based on the idea of conveying to the general } \\
\text { public the idea of the uniqueness of the territory. }\end{array}$ \\
\hline
\end{tabular}

Source: own elaboration.

Hence the brand of the territory should be considered as a multifactorial system, the structure of which is formed by economic, socio-political, cultural and ideological components. 


\section{Tools for diagnosis and development of the city brand as a tool of public administration}

Just like any managerial process, the process of creating a brand has four stages: planning, organization, coordination and control. Branding a territory in this case does not show significant differences and is subordinate to the same sequence. However, an important preparatory stage of this system is an awareness of the need to use territorial branding technologies.

One of the main current problems in Ukraine is to give consumers an advantage regarding foreign goods and services, as well as the increase of foreign goods and recreational resources over domestic ones. However, the conditions of the COVID-19 pandemic and global quarantine have negatively affected the import and export of products, and also imposed clear restrictions on international tourism and visits to famous tourist destinations in Ukraine, adding to the problem of insufficient exposure of local recreational resources. A similar situation can be seen in many areas of activity in Ukraine, including tourism, higher education, local small businesses and others.

Therefore, the problem of insufficient communication with potential consumers, as well as their certain dislike for local goods and services as stereotypically low-quality or those with low prestige, is highly relevant throughout Ukraine, linked to the decline and impoverishment of small towns, as well as the outflow of labour and financial resources without the return of funds, which actually means the slow death for them. In turn, communication to raise awareness of local resources not only contributes to the formation of the tourist flow, which also brings with it the arrival of financial resources and infrastructure, but also provides support for local entrepreneurship, which has a positive impact on city development by creating new jobs, and contributes to the local budget.

All this necessitates the development and implementation of territorial marketing in Ukraine (Moroz, Gerasimchuk, \& Bondarenko, 2020, p. 26).

However, the effective creation of the city's brand is possible only with the close cooperation of the municipal authorities, the media, business representatives, NGOs and city residents. The process of brand creation should be dynamic, taking the form of a dialogue with internal target audiences. Only in this case is it possible to count on real changes in the image of the city and its effective promotion in the external environment.

Any strategy, regardless of the method or model used, contains three large components that are specific to any cycle which involves iterations, i.e. a repetition of the old model at a qualitatively new level: analysis, planning and implementation. Thus, the development of the city strategy should begin with the actual strategic analysis of the environment, compiling a profile of the local community and conducting sociological research. The next step is planning, which includes the mission, vision, scenarios and directions of the community development. In particular, in order to 
identify the strengths and weaknesses of the city, a SWOT analysis is conducted, on the basis of which a strategy plan is developed, specific goals and objectives are formed, together with projects and measures to achieve the set goals.

The next stage is implementation, which involves public discussion and the perception of the plans by the community, the development of targeted programmes and activities, monitoring and evaluation of the achieved results, as well as the revision and adjustment of the strategy. Thus a new strategy is developed or the old one is adapted, taking into account the shortcomings found (Pochtovyuk \& Bondarenko, 2020).

Domestic and foreign researchers have studied the methods of developing the city's brand, for example, Ripka identified the following stages of branding a city (Ripka, 2011):

1. Accurate formulation of the problem for setting goals and objectives.

2. Preparation of a solution, which means working out ways to achieve the goals, options for possible actions, and compare them with each other, taking into account the efficiency of resource use.

3. Decision-making, i.e. the choice and consolidation of ways to achieve the task, which are most rational when taking into account the conditions of the company.

4. Coordination of actions, planning and organization of the implementation of decisions.

5. Monitoring and evaluation of the results.

Matlovychova identified the following stages of creating a city strategy: motivation, analysis, definition and implementation (Matlovychova, 2008). Azaryan et al. defined such general stages as segmentation, selection of the target segment, brand creation, and communication (Azaryan et al., 2009, p. 280), namely such technology that can be used to form a brand in any locality. Some scholars have tried to consider certain elements of the branding of the locality, such as the definition of target audiences and attributes of the city's brand, but there is a need to combine these separate findings into one system for the formation of a certain template of the creation of the city brand. The algorithm for creating a brand includes the following actions:

- definition of internal and external identity,

- choice of positioning, uniqueness of the territory,

- development of visual images of the territory,

- promotion (Demkura, 2013).

The consideration of the category of territorial branding as a tool of public administration involves a reference to the concept of strategy. In fact, today the intangible component of regional development is becoming a new tool to increase its position, competitiveness, and socio-economic development. Branding is a complex process of brand management through the use of marketing and management strategies. In general, the strategy of brand-oriented public city management is 
a process of step-by-step informed decision-making on brand development in the region.

Taking into account all these features on the basis of the previous research, the tools for the diagnosis and development of the territorial brand were identified and formed. Figure 1 shows the tools for the diagnosis and development of the territorial brand.

In particular, the following stages are highlighted:

1. Analysis of the identity and competitiveness of the city.

2. Assessment of strategic directions of development and target audiences of the city brand.

3. Synthesis of strategic directions of city development.

4. Defining target audiences.

5. Assessment of image competitiveness.

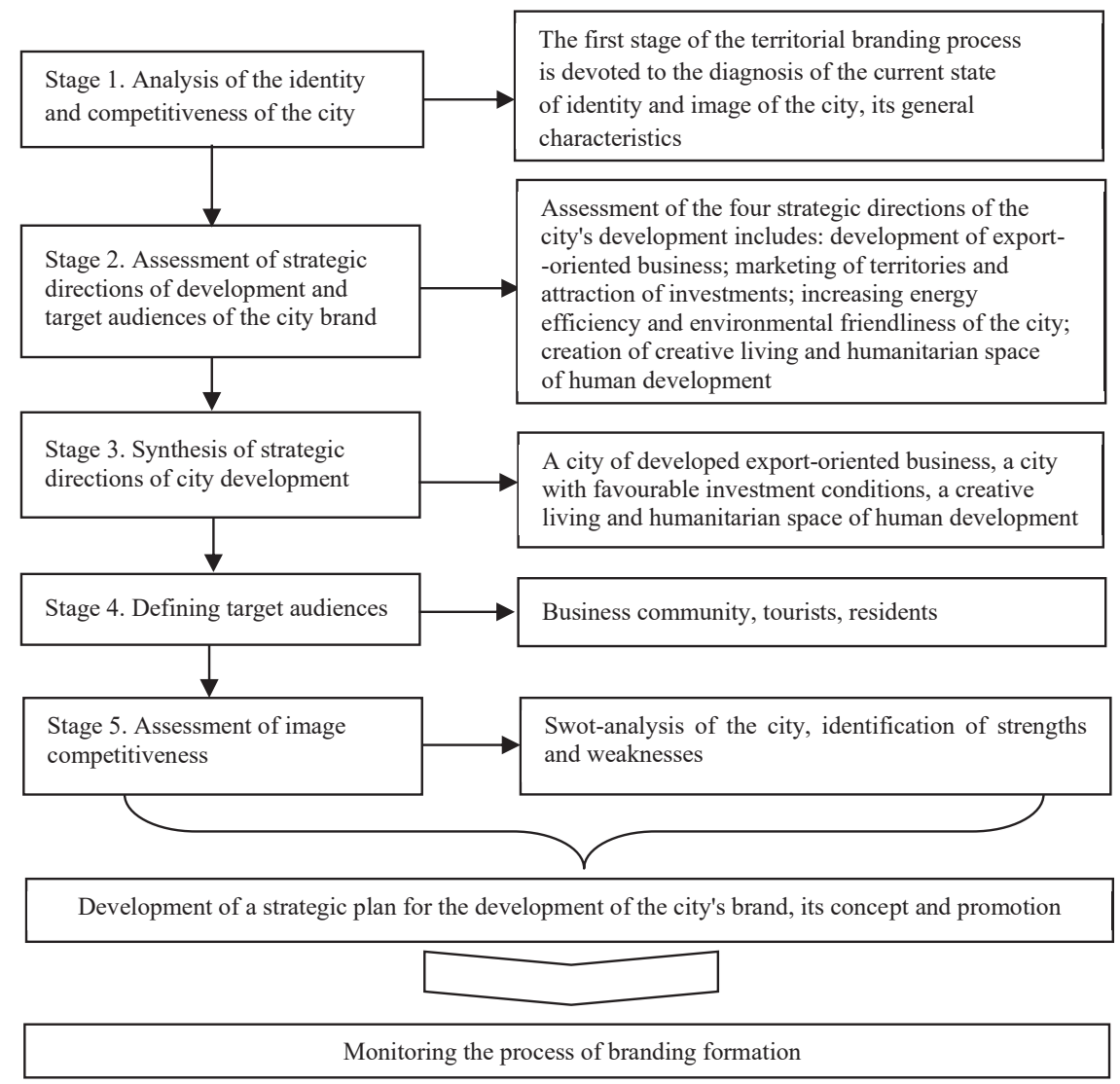

Fig. 2. Tools for the diagnosis and development of the city brand as a tool of public administration Source: author's elaboration. 
The first stage of the branding process is devoted to diagnosing the current state of identity and image of the city. Analysis of the current image and identity of the selected area takes into account the implementation of certain stages that allow to form the most complete picture of reality with minimal effort. In particular, the analytical stage includes an analysis of the city's individuality and image, a synthesis of areas of work and goals to be achieved through the formation of the city's brand, and the selection of target audiences that the brand will focus on, as well as assessing the competitiveness of the city's image.

The priority at the analytical stage of the city's branding process is the characterization of its features, allowing to distinguish the city from others. To position the city, to choose its competitive uniqueness, its identity is studied, which is characterized by the peculiarities of the city and the perception of the city by its inhabitants. On the basis of a certain identity, the ideological basis of the city is later chosen. There are internal and external aspects of the identity. Internal, i.e. urban identity is a set of different qualities and characteristics that can distinguish the city from among many others and facilitate the process of recognizing it, to make it unique.

External, i.e. the image of the city, is a set existing in the public consciousness of stable ideas about the city, formed on the basis of information. Based on the chosen urban identity, the desired result of the city's branding is determined.

City branding is closely connected with its image and individuality. The strategy of forming the identity of the location, the brand policy and its reflection in the image are interconnected elements and therefore impossible to perceive separately. The well-known brand of the place means that people know about it, and thanks to the brand they have certain associations about it. Analysis and differentiation of brands and their impact on the final image is an important basis for further market segmentation and the possible modification of identity as a set of characteristics of the city, which is considered as a marketing product. Brands and their images not only allow to be identifiable, but also reveal in what capacity they are perceived. It is important for the city to identify, analyse and then qualitatively convey their image, because if they do not pay enough attention to this activity, a stronger image can hurt - branding will become a brand (Demkura, 2013), which may not only not contribute to the creation of a more attractive image, but also to establish in the minds of target audiences a negative image of the city. A poor perception of the city can lead to a devaluation of its image, with far-reaching consequences in terms of the possibility of future prosperity. The presence of negative associations can have a long-term impact and hinder future investments in the activities of local companies, and also a devastating effect on the number of visitors, and thus contribute to its deterioration and decline.

Yet, brand development can reverse the trend of decline and begin to revive the processes taking place in the city (Truman, Klemm, Giroud, \& Lindley, 2003). Its identity of is the result of a planned activity within the framework of territorial 
marketing projects and, in contrast to the image, it is considered as an objective state of its perception of. Identity is also described as the sum of characteristics that distinguish one city from another.

In addition, brand development is an active part of marketing planning that can be influenced, whereas the image formed as a result of marketing communications is a passive process. Aaker (2003) compares identity to place and argues that "place identity is like a niche you are looking for to be noticed. A place identity is a unique set of associations that denote the place that management wants to create or maintain. Associations represent what a place means and what it promises through local organizations."

The image of a city, as opposed to the identity, is a set of subjective thoughts, ideas and feelings about it, and each image is a simplification of a large number of associations and partial information related to that place (Kotler, Asplund, Rhine, \& Haider, 1999, p. 388).

Based on the previous characteristics, it can be argued that identity, brand and image are interrelated elements of the product - i.e. the city.

There are many methods of studying the current image of the city: focus group, expert evaluation method, interview method, projective methods (design, associative method, ranking, task completion, expressive method), semantic differential, and the multidimensional analytical map method.

The most common tool for studying the current image of the city, i.e. the semantic differential, allows to detect deviations of the current image from the desired one. This method is based on a public opinion poll on a representative sample of respondents and an optimized set of criteria offered to them. In the case of small deviations, this concerns a unique image, and in other cases a blurred image. Even though it may seem natural that efforts will be focused on unambiguity, in reality this is not the case, and often blurred images are preferred (Kotler, 2001, p. 720).

However, the most accessible method is the interview method, based on the interviewer's direct contact with the respondents. The information collected during the survey needs further structuring in the form of a map of associations, which allows to trace the existing chains of associations with the studied location.

The second stage is the assessment of strategic directions of development and target audiences of the city brand. The next element of the analytical stage is to determine the directions of development and goals to be achieved by the brand. Determining the directions of brand development and its goals should be based on a strategic plan for the development of the territory. The focus of the city's branding with its strategic development plan is one of the keys to its success.

The strategic plan for the development of the territory is the basis and foundation for the brand, identifies the main objectives of the brand and gives it direction. Taking into account the planned development, the promotion of its interests becomes purposeful and meaningful. In a territory that has a clear strategy, it is easier to develop a brand plan, the success criterion of which will be the achievement of 
strategic performance indicators. The strategic plan answers the question of what is the goal and what results should be achieved. The branding answers the question of how and with what tools to promote the given territory. Thus, the brand is one of the main tools for implementing the strategic plan, as well as a way to achieve its goals. That is why for the successful implementation of city branding it is important to pay attention to the strategic goals and objectives facing it, and to focus on them in the process of positioning the city. Like individuality, development goals have a decisive influence on the result of branding, because it is on the basis of individuality and goals that the brand identity is developed, namely a set of ideas and images that distinguish the brand from others.

Additionally, the analytical stage of the city's brand formation requires the selection of target audiences. It is the accuracy of the selection of target audiences that determines how successful and useful the result of brand implementation will be.

Kotler and Armstrong (2004) argue that there is no single way to segment the market. Marketers are often forced to try different segmentation methods, either as separate methods or in different combinations with each other, so that they can find a better overview of the market structure. In the case of cities, the complexity of segmentation increases in proportion to the heterogeneity of the product, therefore it is quite difficult to find a universally applicable system of criteria. The most common classification in the literature involves the criteria divided into three main groups: geographic, demographic, psychographic/behavioural criteria.

The third stage is a synthesis of strategic directions of the city development. namely: the city of developed export-oriented business, the city with favourable conditions of investment, creative living and space of personal development.

The fourth stage is the definition of target audiences. In the process of analysis in the second stage, in addition to the synthesis of strategic directions of development in the third stage, there is also the need to identify target audiences.

The fifth stage is an assessment of the city's competitiveness. For this purpose, it is advisable to use a SWOT analysis, one of the main tools of situational analysis, designed for strategy development and programme development. It can also be seen as the basis for answering the question of what is the state of the city and where is it going in the future. In principle, the strategy of the city's further development can be based on its strengths, unless they are affected by weaknesses or threats that cannot potentially be eliminated or reduced.

Thus, in the end, the concept of the city brand is formed on the basis of the mission and purpose of the brand, as well as its values, which are determined on the basis of the strategic directions of the city. The concept of the city brand should reflect its individuality. 


\section{Directions of promotion of the city brand as a factor in increasing its competitiveness}

The previously formed concept of the city brand needs further development and formulation in the direction of each target audience, i.e. the cultivation and formation of the desired image of the city in the minds of the target audiences of the brand. On the basis of the previously formed concept of the image and taking into account the strengths of the existing image, messages are formed for the target audiences, which should focus on the strengths of the city interesting for the representatives of the target audiences, meet their values and offer them opportunities to develop and implement their ideas and opportunities in the city. Thus, the purpose of positioning the city for certain target audiences - potential investors, guests (tourists) and city residents - is to create in their minds a unique, different image of the city, as well as highlight the desired niche in selected markets. To do this, it is necessary to formulate and position a set of certain values that the city can offer to this audience.

However, it is not enough to formulate the desired image in the minds of target audiences, because in the absence of its reinforcement in reality, it will not only be unstable, but also undermine the trust of target audiences in the city in the future.

That is why projects are needed to 'grow' the brand in certain areas of urban life. In particular, projects aimed at brand visualization and consolidation should be implemented in the urban environment and infrastructure, and those aimed at reviving brand perception in the cultural and information environment of the city.

Brand management requires a certain organizational basis of branding, in particular the regulatory and institutional support of city marketing.

Projects to cultivate the brand in the urban space are aimed at:

1. Target audience, namely potential investors: development of urban infrastructure; improving the security of doing business; preparation of investment products and support of the investment portal; motivating enterprises to update the material and technical base; introduction of energy efficient technologies in urban space. Hence when positioning the city to potential investors, it is advisable to rely on such brand values as: energy efficiency, innovation, technology, education, openness, and readiness for change.

2. Target audience, namely tourists: creation of infrastructure for recreation in the coastal zone and greenery; creation of excursion routes; creation and development of tourist infrastructure.

3. Target audience, namely city residents (internal marketing). No less important in the marketing of the place is the internal audience. It is the residents who create the atmosphere in the city, and support or level out the promotional brand of the city. It is impossible to overestimate the importance of internal marketing in the process of the city branding. 
To choose ways to promote and promote the city's brand, it is necessary to determine the goals and desired behaviour of the target audiences. It is also appropriate to break down the target audiences into smaller segments, allowing them to communicate more effectively and convey the messages that were formulated in the previous section. In the future, based on the goals of communication and segments, it will be necessary to choose specific ways to promote, describe them and justify the choice. Table 2 presents the target audiences that can contribute to the promotion of the city's brand.

Table 2. Ways to promote the city brand

\begin{tabular}{|l|l|}
\hline \multicolumn{1}{|c|}{ Target group } & \multicolumn{1}{c|}{ Communication channels } \\
\hline 1. Creative leaders & $\begin{array}{l}\text { Creation of joint working groups; preparation and provision of written } \\
\text { analytical materials; web portal of the city, pages in social networks. }\end{array}$ \\
\hline 2. Population & $\begin{array}{l}\text { Public relations; mass media; maintaining a web portal of the city and pages } \\
\text { in social networks; advertising; involvement of famous people in } \\
\text { cooperation with the brand. }\end{array}$ \\
\hline 3. Business & $\begin{array}{l}\text { Direct marketing (promotion of the city brand directly during business } \\
\text { forums, conferences and business trips), event marketing, business and } \\
\text { industry media. }\end{array}$ \\
\hline 4. Mass media & $\begin{array}{l}\text { Preparation of comments, articles and reviews; holding events for } \\
\text { journalists. }\end{array}$ \\
\hline 5. External audience & $\begin{array}{l}\text { Business and industry national and international media, creation and support } \\
\text { of investment and tourist web portal, involvement of tour operators. }\end{array}$ \\
\hline
\end{tabular}

Source: own elaboration.

It can be noted that each target audience finds opportunities in the city to achieve their goals. However, to create the desired image in the minds of target audiences requires not only long-term activities to grow the brand in the urban environment through the implementation of the proposed projects, but also the implementation of effective communication activities. The main channels for promoting the city brand are: communication through the media, public relations, events, direct marketing, and promotion on the Internet. For all target audiences, different orientation media are very relevant channels of communication. In addition, to attract representatives of the target group of investors, the most effective means of communication is direct marketing, as well as the organization and participation in business-related activities, While conveying information to the target audience of tourists mainly requires communication through secondary audiences: tour operators, travel service providers and well-known travel bloggers. The target audience of population, in addition to communication through the media and the Internet also requires the construction of a reliable system of public relations, as well as the involvement in the process of promoting the brand of opinion leaders and celebrities. 


\section{Conclusion}

The city's branding reflects its identity because cities and places are not just about tourism, exports or real estate. Identity also takes into account the self-determination of the local population, culture, heritage, symbols, leadership, collective sense of belonging and heterogeneity. Thus, the creation of brand capital, i.e. the recognition of the name, image and loyalty, should begin with defining the individuality of the city and building a comprehensive strategy and policy focused on supply, taking into account competitiveness rather than demand. City branding is closely related to place marketing, but is also a separate area of research and practice.

According to the proposed tools, the process of developing a territorial brand consists of three stages. The purpose of the first stage is to diagnose the current state of the city brand, analysis of its identity and image, synthesis of directions of city development, determination of target audiences and assessment of the competitiveness of its image. The second stage involves synthesis of the concept of the brand, determining its positioning and ways of promotion. The third stage is control, designed to assess the effectiveness of the implemented measures and identify shortcomings, also taking into account the monitoring of international experience.

\section{References}

Aaker, D. (2003). Building a brand. Brno: Computer Press.

Anholt, S. (2010). Definitions of place branding - working towards a resolution. Place Brand Public Dipl., (6), 1-10. doi.org/10.1057/pb.2010.3

Azaryan, O. et. al. (2009). Strategy of effective branding. Donetsk: Donetsk National University of Economics and Trade named after Mikhail Tugan-Baranovsky.

Demkura, T. (2013). Formation and development of integrated marketing communications: Theoretical aspect. Galician Economic Bulletin, (4), 207-214.

Kavaratzis, M., \& Ashworth, G. J. (2005). City branding: An effective assertion of identity or a transitory marketing trick? Tijdschrift voor economische en sociale geografie, 96(5), 506-514.

Kolesnytska, N. (2012). Territorial branding: Scientific and methodological approaches to definition and formation. Scientific Works of Petro Mohyla Black Sea State University. Ser.: Political Science, 197(185), 47-50.

Kotler, P. (2001). Marketing management. Prague: Grada Publishing House.

Kotler, P., \& Armstrong, G. (2004). Principles of marketing. Prague: Grada Publishing House.

Kotler, P., Asplund, K., Rhine, I., \& Haider, D. (1999). Marketing of places in Europe. London: Pearson Education Ltd.

Matlovychova, K. (2008). The place of the marketing process - theoretical aspects of implementation. Acta Facultatis Studiorum Humanitatis et Naturae Universitatis Presoviensis, Folia Geographica, $12,195-224$.

Moroz, O. V., Gerasimchuk, V. V., \& Bondarenko, A. O. (2020). Communication tools in city brand formation. Eastern Europe: Economy, Business and Management, 3.

Olefirenko, O. (n.d.). Problems of theory and practice of branding of territories based on the example of the concept of brand formation of the Sumy region. Retrieved September 13, 2021 from http: // mmi.fem.sumdu.edu.ua/39 
Pochtovyuk, A. B., \& Bondarenko, A. O. (2020). Analysis of the strategy of sustainable development of the city of Kremenchuk. Scientific notes of Tavrida National V.I. Vernadsky University: Economic Sciences, 31(70), 44-51.

Pomaz, I., Fedorovich, E., \& Guts, O. (2020). City brands: Necessity and methodology for territory marketing. Minsk: Belarusian State Economic University.

Ripka, Yu. (2011). Prerequisites and stages of formation of the brand of the settlement. Theory and Practice of Public Administration, (3).

Seppo K. Rainisto (2003). Success factors for place marketing: A study of place marketing practices in Northern Europe and the United States. Espoo: Helsinki University of Technology.

Soldatenko, I., \& Posylnyi, I. (2019). Mass communication as a tool for branding the city. Sociological Studies, 2(15), 55-63.

Truman, M., Klemm, M., Giroud, A., \& Lindley, T. (2003). Bradford in the Premier League? Multidisciplinary approach to branding and repositioning of the city. The letter was sent to the European Journal of Marketing (Working Paper /04 01/04). Bradford: School of Management, University of Bradford.

Zhitar, O. L. (2009). Theoretical principles of city branding. Bulletin of Khmelnytsky National University, (6), 68-72. 